\title{
Continuous Quality Improvement to Meet the Gold Standard of Growth Monitoring in Acute Admissions
}

Dr Suzanne Milne ${ }^{1}$, Dr Katherine Jarman ${ }^{1}$, Dr Natalie Bee ${ }^{2}$

Acute Medical Receiving Unit, Royal Hospital for Sick Children, Edinburgh, UK

\section{Background}

The Royal College of Paediatrics and Child Health $(\mathrm{RCPCH})$ guidance recommends growth monitoring if there is concern regarding a child's general health ${ }^{1}$. Missed growth assessments are highlighted in serious case reviews ${ }^{2}$. Acute admissions present an opportunity to review growth and assess for faltering. Electronic growth charts are accessible by the multi-disciplinary team within NHS Lothian.

\section{Aims}

- To establish if current practice for monitoring growth is in line with the 'gold standard' from the RCPCH.

- To establish a continuous quality improvement initiative to achieve a higher standard.

\section{Method}

- Monthly spot audits of medical inpatients (total $=114$ ) performed between September 2017 and January 2018. Interventions were undertaken between each spot audit.

- Included: acute receiving unit (ARU) patients who had been clerked and reviewed on a consultant ward round at time of data collection.

- Excluded: critical care or subspecialty admissions.

- Measurements collected: height/length and weight, plus occipitofrontal circumference (OFC) in children under two years old.

- Target set to plot $90 \%$ of admissions.

\section{Figure 1- Interventions undertaken}

\begin{tabular}{|l|l|} 
- Presentation at hospital-wide Grand Round \\
$\begin{array}{l}\text { Deeting } \\
\text { and quality improvement emails) }\end{array}$ \\
\hline Int
\end{tabular}

\section{Results}

- Plotting of weight improved from $32 \%$ in September to $60 \%$ in October following $1^{\text {st }}$ intervention. Subsequent drop to $50 \%$ in November, with recovery to peak of $71 \%$ in December. Compliance remained relatively stable at $65 \%$ in January.

- OFC followed a similar trend, improving from 33\% in September to $58 \%$ in January, with a peak of $62 \%$ in December.

- Height/length was poorly documented in $<20 \%$ patients, all months.

\begin{tabular}{|c|c|c|c|c|c|}
\hline & Sept 17 & Oct 17 & Nov 17 & Dec 17 & Jan 18 \\
\hline Age range & $\begin{array}{l}13 \mathrm{~d}- \\
8 \mathrm{yr}\end{array}$ & $\begin{array}{l}7 \mathrm{~d}- \\
12 \mathrm{yr}\end{array}$ & $\begin{array}{l}6 \mathrm{wk}- \\
14 \mathrm{yr}\end{array}$ & $\begin{array}{l}8 \mathrm{~d}- \\
13 \mathrm{yr}\end{array}$ & $\begin{array}{l}7 \mathrm{~d}- \\
11 \mathrm{yr}\end{array}$ \\
\hline Total no. of pts & 19 & 20 & 20 & 35 & 20 \\
\hline $\begin{array}{l}\text { No. of pts with } \\
\text { weight plotted }\end{array}$ & $\begin{array}{l}6 \\
(32 \%)\end{array}$ & $\begin{array}{l}12 \\
(60 \%)\end{array}$ & $\begin{array}{l}10 \\
(50 \%)\end{array}$ & $\begin{array}{l}25 \\
(71 \%)\end{array}$ & $\begin{array}{l}13 \\
(65 \%)\end{array}$ \\
\hline $\begin{array}{l}\text { No. of pts with } \\
\text { height plotted }\end{array}$ & $\begin{array}{l}0 \\
(0 \%)\end{array}$ & $\begin{array}{l}2 \\
(10 \%)\end{array}$ & $\begin{array}{l}0 \\
(0 \%)\end{array}$ & $\begin{array}{l}4 \\
(11 \%)\end{array}$ & $\begin{array}{l}4 \\
(20 \%)\end{array}$ \\
\hline $\begin{array}{l}\text { No. of pts < } 2 \\
\text { years }\end{array}$ & 12 & 14 & 14 & 29 & 12 \\
\hline $\begin{array}{l}\text { No. of pts }<2 \\
\text { years with OFC } \\
\text { plotted }\end{array}$ & $\begin{array}{l}4 \\
(33 \%)\end{array}$ & $\begin{array}{l}8 \\
(57 \%)\end{array}$ & $\begin{array}{l}5 \\
(36 \%)\end{array}$ & $\begin{array}{l}18 \\
(62 \%)\end{array}$ & $\begin{array}{l}7 \\
(58 \%)\end{array}$ \\
\hline
\end{tabular}

\section{Discussion}

- Continuous quality improvement allows for rapid identification of falling targets, facilitating timely intervention.

- Our results demonstrate an overall responsiveness towards educational intervention.

- Limitations: daily variability not identified through monthly audit, measurements taken but not electronically plotted were not counted.

- Larger sample size in December as hospital busier.

Figure 2 - Percentage of admissions with weight and OFC plotted with timeline of interventions annotated.

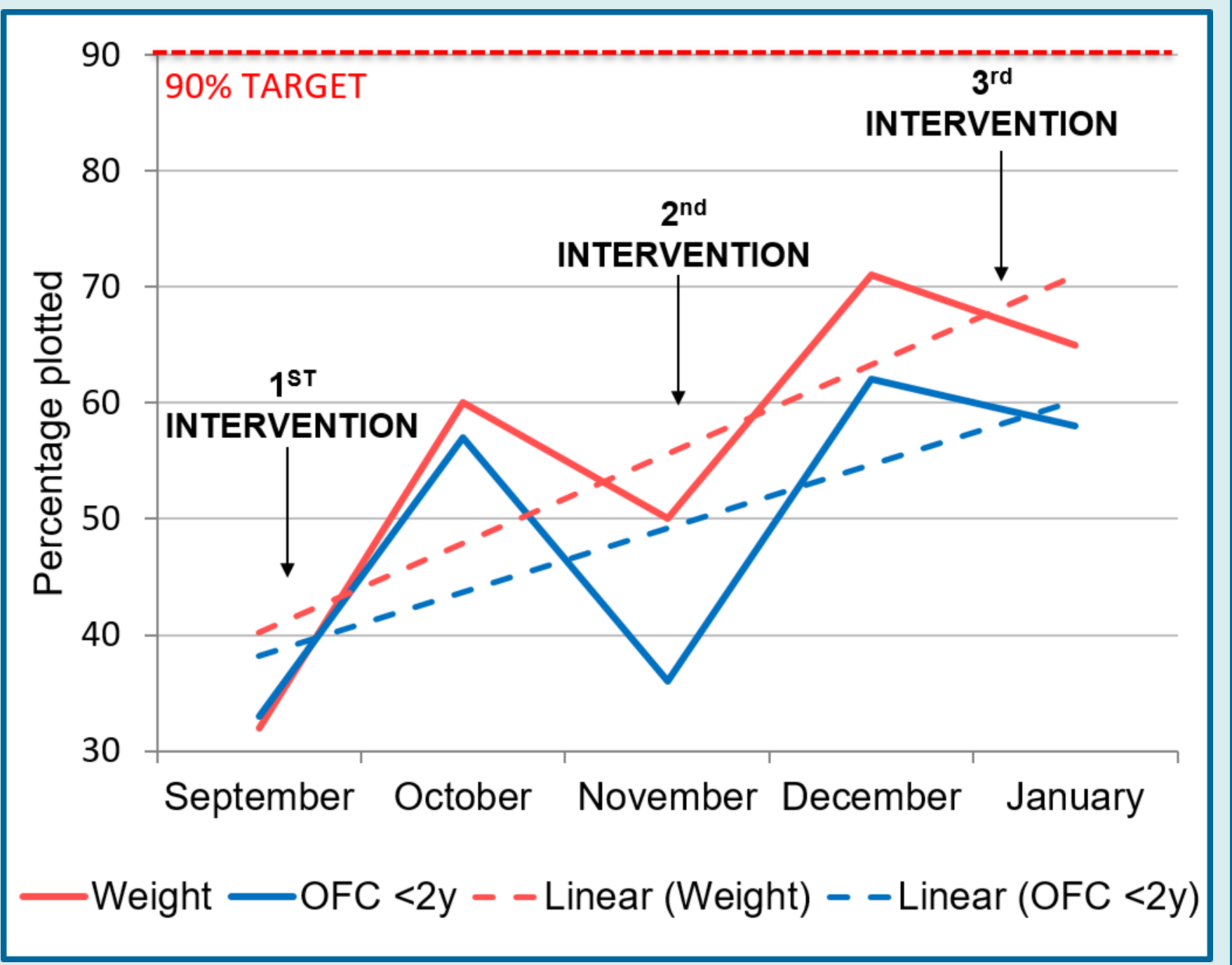

\section{Conclusions}

- Overall improving trend in documentation of weight and OFC on admission to ARU; height remained poorly documented.

-The second intervention was the most effective.

-Results demonstrate the need for continuous team education to maintain any improved standard. This is ongoing in our department.

- This project is relevant to all paediatric departments. 